\title{
Mesoscale distribution patterns of diatoms in surface sediments as tracers of coastal upwelling of the Galician shelf (NW Iberian Peninsula)
}

\author{
Roberto Bao ${ }^{\mathrm{a},{ }^{*}}$, Manuel Varela ${ }^{\mathrm{b}}$, Ricardo Prego ${ }^{\mathrm{c}}$ \\ a Departamento de Xeoloxia, Universidade da Coruña, Facultade de Ciencias, Campus \\ da Zapateira s/n, 15071 A Coruña, Spain \\ ${ }^{\mathrm{b}}$ Instituto Español de Oceanografia, Centro Costero de A Coruña, Apartado 130, 15080 \\ A Coruña, Spain \\ ${ }^{\mathrm{c}}$ Instituto de Investigaciones Marinas (CSIC), Eduardo Cabello 6, 36208 Vigo. Spain \\ *Corresponding author. E-mail: xerobert@udc.es
}

\section{Abstract}

Diatom distribution on continental shelf sediments from the upwelling area off Galicia (NW Iberian Peninsula) has been determined in 78 surface sediment samples. Three well defined biofacies with a close relationship to upwelling influence along the coast have been distinguished from both the absolute diatom abundances in the sediments and assemblage diatom composition based on multivariate statistics: Rias Baixas and the shelf areas south and north to Cape Finisterre. Chaetoceros resting spores as well as highest absolute diatom content in the sediments are recorded in the highly productive Rias Baixas where most of the primary production is due to intense upwelling phenomena. The western shelf, south of Cape Finisterre, is characterized by Thalassionema nitzschioides and Thalassiosira cf. leptopus. Both taxa reflect a minor influence of upwelling conditions and productivity related to more persistent nutrient input due to coastal outwelling rather than upwelling. Minor and patchy upwelling conditions as well as lower productivity in the northern shelf are characterized by the lowest absolute diatom content in the sediments and the important increase in relative abundance of the resistant Paralia sulcata. Caution must be taken in the interpretation of Paralia sulcata dominated biofacies in downcore studies since a juxtaposition of discontinuous upwelling conditions and dissolution effects may be the factors responsible for the relative increase on the taxon in the sediments. The obtained results show the extent and limitations of fossil diatom distribution in surface sediments as tracers of regional coastal upwelling conditions in continental shelves where the 
existence of extensive areas of relict sediments and transported diatoms may mask the present-day upwelling signal of the photic zone.

Keywords: diatoms; paleoceanography: upwelling; continental shelf; NW Iberian Peninsula; micropaleontology

\section{Introduction}

The rias and continental shelf off Galicia (Fig. 1) are amongst the most productive oceanic regions of the world (Blanton et al., 1984), mainly due to upwelling (Prego, 1993). The upwelling system off the Galician coast is associated with the north Atlantic anticyclonic gyre (Wooster et al., 1976). The general hydrographical effects of upwelling off the Galician coast have been studied during the last two decades (Fraga, 1981; Fraga et al., 1982; Blanton et al., 1984; McClain et al., 1986; Tenore et al., 1995) but a detailed mesoscale description of upwelling patterns in the Galician coast has still not been considered until recently (Prego and Bao, 1997). Using the hydrodynamical and biological characteristics of upwelling, the Galician shelf waters can hypothetically be divided into two contrasting sectors south (western shelf) and north (northern shelf) of Cape Finisterre (Estrada, 1984; Tenore et al., 1995; Prego and Bao, 1997). A third hydrodynamically delimited area, the Rias Baixas, could be defined according to its characteristic positive residual circulation (Prego, 1990).

The impact of upwelling on Quaternary sediments of the rias and continental shelf has only superficially been studied (Rey and Diaz del Rio, 1987; Lopez-Jamar et al., 1992; Prego et al., 1995; Prego and Bao, 1997). Although fossil diatom assemblages in surface sediments of upwelling affected areas have been proven as powerful upwelling indicators (Schuette and Schrader, 1981 a,b; Abrantes, 1988; Schrader and Sorknes, 1991), there are only a few studies of the fossil diatom composition of the rias and shelf sediments of the Galician area and these (e.g. Margalef, 1959) do not deal directly with upwelling processes in the water column.

The fossil diatom record of shallow marine environments remains less studied than deep-marine environments. Sediments of continental shelves consist of sediments in equilibrium with present day conditions and relict sediments (Kennett, 1982). If 
preserved, the interpretation of upwelling signals in surface sediments of the shallow seas may be complex. This is the case of the Galician coast where evidences of palimpsest sediments (McManus, 1975) have been found in the outer shelf indicating past low-stands in sea-level (Bao et al., 1995). In some cases no evidence of upwelling imprinting in the underlying bottom sediments of the continental shelf of a major upwelling system can be found (Fütterer, 1983). The reconnaissance of characteristic shallow water upwelling facies is therefore relevant for the paleoceanographic reconstruction of upwelling conditions on a regional scale in the epicontinental seas.

In this paper the diatom distribution in surface sediments of the Galician shelf is studied in order to test the hypothesis that diatom assemblages can be used as tracers of the main hydrographical and biogeochemical processes taking part in the Galician coastal waters according to three well defined geographical sectors where upwelling has a different incidence: western shelf (south of Cape Finisterre), northern shelf (north of Cape Finisterre) and the Rias Baixas.

\section{Material and methods}

Surface sediment samples were collected during the Breogan cruises between 1984 and 1987 by the Instituto Español de Oceanografia and the University of Maryland. Seventy-eight box corer sediment samples were selected for fossil diatom study (Fig. 1; Table 1). Three samples were rejected because of the scarcity of diatoms.

A known weight of dry sediment sample was treated with $\mathrm{HCl}, \mathrm{KMnO}_{4}$ and oxalic acid in order to eliminate carbonate and organic matter. $0.5 \mathrm{ml}$ of treated subsample was strewn evenly onto cleaned 22 × $22 \mathrm{~mm}$ glass coverslips. Slides were mounted with $\operatorname{Hyrax}(\mathrm{n}=1.7)$.

Diatom counts were made at $1250 \mathrm{x}$ following random transects using a Nikon Optiphot microscope with Nomarski differential interference contrast. In general, 200-300 valves were counted per sample. Countings and total number estimates were made following Schrader and Gersonde (1978). Raw counts were converted to percent abundances. Diatom accumulation rates could not be calculated because there are no sedimentation 
rate data for the Galician shelf so, absolute abundances are expressed as valves per gram of dry sediment.

Diatom preservation in each sample was estimated following the degree of dissolution of the margin of the omnipresent Paralia sulcata (Abrantes, 1988): Paralia sulcata (p.p.)/P. sulcata (w.p.) + P. sulcata (p.p.), where p.p. is poorly preserved (specimens showing dissolution at the margin) and w.p. is well preserved. Values close to zero are indicative of a good preservation.

In order to characterize differences between groups of samples from three geographically defined areas (Rias Baixas, shelf north of Cape Finisterre and shelf south of this cape), a discriminant analysis was conducted (Williams, 1983). Descriptive discriminant analysis seeks to exhibit differences among samples grouped according to an external criterion (geographic location in this case) by means of linear combinations of the observation variables (diatom taxa relative abundances). Computations were based on the correlation matrix of relative abundances. Only the taxa with relative abundances greater than $2 \%$ in at least $5 \%$ of the samples were included in the analysis. Sample numbers 35, 36 and 100 showed a high number of fragmented diatoms and/or anomalous specific composition and so were excluded from the analysis. Three of the species from the resulting matrix did not show significant differences in average relative abundances (Cocconeis disculoides $F_{2.70}=2.860 \mathrm{p}=0.064$; Cocconeis placentula $\mathrm{F}_{2.70}=$ $2.121 \mathrm{p}=0.28$; Cocconeis scutellum $\left.\mathrm{F}_{2.70}=0.079 \mathrm{p}=0.925\right)$. TO maximize the resolution of discriminant function these three species were not included in further analysis.

\section{Oceanographic setting}

Quasi-permanent upwelling of Eastern North Atlantic Central Water (ENAW) occurs off the coast of Galicia from April to August, and may persist up to October (Fraga, 1981). In the vicinity of Cape Finisterre a front between two water masses of ENAW of different origin is formed (Rios et al., 1992). South of Cape Finisterre the ENAW has a subtropical origin and is called ENAW . North of the Cape it- has a subpolar origin, is

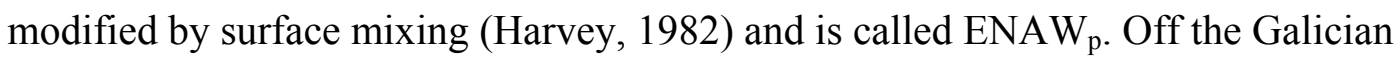
coast $\mathrm{ENAW}_{\mathrm{t}}$ moves northward while $\mathrm{ENAW}_{\mathrm{p}}$ moves from north to west. The two 
water masses converge in the Finisterre Cape area resulting in an offshore extension of upwelling (Rios et al., 1992). Additionally, over the western shelf, surface waters during the summer move in different direction than $\mathrm{ENAW}_{\mathrm{t}}$, causing an intensification of upwelling which is associated with an increase in relative velocities of both water masses (Fraga et al., 1982). This intensification does not occur on the northern shelf where the surface and subsurface water fluxes move in the same direction.

Although upwelling dynamics is driven by large atmospheric processes, smaller scale processes are biologically more important (Blanton et al., 1984). Topography is a determinant factor in the intensification of upwelling off the Galician coast. Vorticity numerical models suggest an intensification of upwelling near Cape Finisterre (Blanton et al., 1984). The effect of winds on upwelling differs between the shelf sectors. North winds intensify upwelling in the western shelf (south of Cape Finisterre) while southeast winds do so on the northern shelf (north of Cape Finisterre) (McClain et al., 1986). It has also been considered that south of Cape Finisterre upwelling is more intense and closer to the coast while in the north it is discontinuous and keeps close to the margin (Prego and Bao, 1997).

The presence of the Rias Baixas in the western coast adds considerable complexity to the oceano graphic setting. The rias are flooded tectonic valleys with a positive residual circulation pattern which, following Prego (1990), may be classified as partially stratified estuaries, lower salinity surface water flows out from the rias and is compensated for by oceanic water flowing into along the bottom.

Nutrient inflow due to upwelling inside the Rias Baixas can reach $300 \mathrm{~g} \mathrm{~s}^{-1}$ of nitrate, 25 $\mathrm{g} \mathrm{s}^{-1}$ of phosphate and $60 \mathrm{~g} \mathrm{~s}^{-1}$ of silicate (Prego, 1990). Besides this, nutrient concentration may also increase due to the remineralization of the organic matter synthesized inside the rias and transported by positive residual circulation, a process which takes place essentially at the mouth. This remineralisation enriches the subsurface water inflow which brings the nutrients back into the ria (Estrada, 1984).

High nutrient levels induce high levels of phytoplankton primary productivity. In winter primary productivity in the Rias Baixas fluctuates between 30 and $100 \mathrm{mg} \mathrm{C} \mathrm{m}^{-2}$ day $^{-1}$ (Tenore and Gonzalez, 1975; Gonzalez et al., 1982) while in spring, summer and fall it 
fluctuates between 700 and $3700 \mathrm{mg} \mathrm{C} \mathrm{m}^{-2}$ day $^{-1}$ (Nunes et al., 1984; Prego, 1993). Average levels of phytoplankton primary productivity are $250-260 \mathrm{~g} \mathrm{C} \mathrm{m}^{-2}$ year $^{-1}$, three times higher than in oceanic areas of the same latitude, a value comparable only to regions with strong upwelling or neritic environments with a high continental nutrient supply (Varela et al., 1984). Between spring and fall, primary productivity in the shelf waters fluctuates between 570 and $1140 \mathrm{mg} \mathrm{C} \mathrm{m}^{-2}$ year $^{-1}$ (Bode et al., 1994), levels similar to those of the NW African upwelling system (Huntsman and Barber, 1977).

The annual cycle and biomass levels of phytoplankton in the Rias Baixas are controlled by inflow pulses of ENAW due to upwelling with peak biomass levels during the summer (Varela, 1992). As in the Rias Baixas, phytoplankton abundance and distribution in the shelf is affected by upwelling patterns. Maximum primary productivity and phytoplankton biomass are recorded during the upwelling season with a clear predominance of net phytoplankton where diatoms are, by far, the most important group (Bode et al., 1994).

Differences in phytoplankton characteristics between the northern and western coastal areas are mainly due to the presence of the Rias Baixas south to Cape Finisterre and different upwelling intensities. Chlorophyll a concentration is 2.5 times higher on the western than on the northern coastal area during upwelling seasons (Fraga et al.. 1982). Opposite circulation of surface and subsurface waters in the western shelf area, which reinforces upwelling, may have a direct repercussion on phytoplanktonic biomass (Estrada. 1984). The presence of the Rias Baixas may also influence higher biomass levels in the western shelf and it affects the phytoplankton community composition due to species of the rias being exported to the open ocean (Estrada. 1984).

\section{Results}

Fig. 2a shows absolute diatom abundances. Maximum values are recorded inside the Rias Baixas and the near shelf, while lowest abundances are recorded in the northern shelf and some offshore areas of the western shelf. All samples inside the Rias Baixas have more than $10 \times 10^{6}$ valves $\mathrm{g}^{-1}$. The Ria de Arousa reaches the maximum value with $87.5 \times 10^{6}$ valves $g^{-1}$. Many samples north of Cape Finisterre show values below $10^{5}$ valves $\mathrm{g}^{-1}$. 
Preservation of diatoms is variable. The distribution of the preservation index (Fig. 2b) shows good preservation in the Rias Baixas and adjacent shelf while poorest preservation conditions occur in an extensive area in the northern shelf. This area also shows an increase in relative abundances of resistant forms such as Trachyneis, Diploneis, Amphora or the copulae of Thalassiosira spp. Many samples in the entire region show a high amount of diatom fragments. Some forms as Asteromphalus flabellatus (Brebisson) Greville, Thalassionema frauenfeldii (Grunow) Hallegraeff or Rhizosolenia spp. appeared only as fragmented material.

Fig. 3 shows the distribution of the most significant taxa found. Chaetoceros spp. resting spores (Fig. 3a) dominate most of the samples from the western shelf and the Rias Baixas. Maximum values are recorded in the highly productive rias. Extensive areas in the northern shelf show a significant diminution in Chaetoceros spp. Percent values, with a more patchy distribution for this region. Thalassionema nitzschioides (Grunow) Hustedt (Fig. 3b) shows its highest values in a western shelf band which runs parallel to the coast from the Ria de Muros to the mouth of the Miño River. Values over $15 \%$ are also recorded in the vicinity of Cape Finisterre and some patches in the northern shelf. Minimum values of Paralia sulcata (Ehr.) Cleve (Fig. 3c) are recorded inside the Rias Baixas and the near shelf. A great number of samples north of Cape Finisterre show values over $20 \%$. Relative abundance distribution of this species is almost the inverse of absolute diatom abundance in the sediments (Fig. 2a).

Discriminant analysis was applied to the three geographically defined groups of samples (Rias Baixas, and shelves to the north and south of Cape Finisterre). A first step in discriminant analysis involves univariate tests of significance which help identify differences among groups considered. Table 2 shows ANOVA results to test the significance of equality of group means for each species. The F values with their corresponding significance levels indicate that significant differences in average abundances for all species included in the analysis were found between the three groups. Table 2 also shows standardized discriminant coefficients of each derived discriminant function and Fisher's classification function coefficients. The absolute values of the standardized discriminant coefficients measure the discriminating power of each taxon for each function. Paralia sulcata and Chaetoceros spp. show extreme values for the first 
discriminant function. Chaetoceros spp. also shows the highest positive value for the second discriminant function while Thalassionema nitzschioides and Thalassisora cf. leptopus shows the highest negative scores. A plot of the standardized discriminant coefficients shows how the species participated differently in the formation of each of the canonical axes (Fig. 4a). The sum of the product of each coefficient by its respective variable in standardized form produced the discriminant scores for each sample, which were then plotted (Fig. 4b). Both plots distinguished the three differently upwelling affected sectors of the Galician shelf and how the species contributed in discriminating the three defined sectors. Samples from the Rias Baixas and northern shelf are discriminated mainly according to relative abundances of Chaetoceros spp. Spores and Paralia sulcata. The western shelf is characterized by Thalassionema nitzschioides and Thalassiosira cf. leptopus.

The value of Wilk's $\lambda$ (a significant index which measures within-group variability with respect to total variability) was 0.184 and so the discriminant resolution of the extracted functions may be considered as very high. Validity of clustering was tested through a Jackknife test of classification (Nie et al., 1975) according to Fisher's linear discriminant function coefficients (Table 3). Correct reclassification of the samples was obtained in $84.7 \%$ of the cases. The lowest reclassification index was for the rias $(81.8 \%)$ and the highest for the northern shelf $(87.5 \%)$.

\section{Discussion}

Fossil diatom distribution in surface sediments of Galician rias and continental shelf may be interpreted according to three geographically defined sectors. Both total diatom numbers in the sediments as well as relative distribution of the taxa suggest a close relationship between the diatom taphocoenoses and the main oceanographic processes controlling the region.

The highest diatom concentrations are found in the Rias Baixas and western shelf sectors. Values of (70-87.5) x $10^{6}$ valves $\mathrm{g}^{-1}$ are reached in the Ria de Arousa. These values are similar to those in the upwelling region of Peru (Schuette and Schrader, 1981a,b; Schrader and Sorknes, 1991) but less than in the SW Africa upwelling region (Schuette and Schrader, 1981a,b). In the rest of the Rias Baixas, the diatom content is 
also very high keeping a close relation with the highest primary productivity levels off the Galician coast of 700-3700 $\mathrm{mg} \mathrm{C} \mathrm{m}^{-2}$ year $^{-1}$ (Tenore and Gonzalez, 1975; Nunes et al., 1984; Prego, 1993). Values around $20 \times 10^{6}$ valves $\mathrm{g}^{-1}$ are observed in the rias of Muros and Pontevedra which may be related, at least in the Ria de Muros, with a lesser incidence of upwelling (Gonzalez et al., 1984). The high productivity in the rias also affects sedimentation on the near shelf due to organic matter export in residual ria currents (Prego, 1990) explaining the high absolute diatom values $\left((2-10)\right.$ x $10^{6}$ valves $\mathrm{g}^{-1}$ ) close to the mouth of the rias. Decreasing absolute diatom abundances from the rias to the shelf show a close relationship with the chlorophyll concentration as well as phytoplankton densities which show decreasing abundances from the rias to the open sea (Varela, 1992). However, the high diatom content in the vicinity of Cape Finisterre may be explained by the topographic intensification of upwelling suggested by vorticity models (Blanton et al., 1984). The discontinuous effect of upwelling in the northern shelf (Prego and Bao, 1997) is reflected in a more patchy distribution of absolute diatom abundances (Fig. 2a). Low values are recorded in an extensive area of this sector probably as a result of low productivity conditions (Bode et al., 1994).

Valve preservation is variable across the Galician shelf. The increase in relative abundances of resistant forms such as Trachyneis or Diploneis, as well as the preservation index distribution (Fig. 2b), suggest an important effect of dissolution on diatom assemblages in the northern shelf sector. However, the decrease of the resistant Chaetoceros spp. spores in the northern shelf suggest (Abrantes, 1991a,b) that different productivity levels in the western and northern shelves are probably the main factor controlling diatom distributional patterns rather than dissolution.

Multivariate analysis shows a good discrimination of samples belonging to the three previously delimited areas as well as the taxa which contribute most to the discrimination of them. The highly productive Rias Baixas are characterized by Chaetoceros spp. resting spores (Fig. 3a), life forms associated with nutrient exhaustion in the water column after massive multiplication of vegetative cells due to an upwelling event (Guillard and Kilham, 1977). Nevertheless there are four other areas where this taxon is also abundant. The first is in the vicinity of Cape Finisterre probably as a result of a topographically induced intensification of upwelling (Blanton et al., 1984). A second area is north of Cape Finisterre, where upwelling is intensified by the 
concurrence of ENAW ${ }_{\mathrm{t}}$ and $\mathrm{ENAW}_{\mathrm{p}}$ and extends offshore (Fraga et al., 1982; Rios et al., 1992). The third sector, close to Cape Prior, includes two patches associated with muds attributed to upwelling related sedimentation processes (Rey and Diaz del Rio, 1987; Prego and Bao, 1997). The fourth sector, in the southernmost part of the western shelf, may be related to the offshore export of Chaetoceros spp. from the rias (Estrada, 1984) as well as to mud bodies originating from suspended fine material coming from the rias and deflected southward by the general prevailing bottom currents (LopezJamar et al., 1992). This is also supported by evidences that periods of upwelling relaxation produce an abutting of exportation from the rias confining all the material over the shelf and transporting it towards south by geostrophic currents (Figueiras et al., 1997).

Thalassionema nitzschioides and Thalassiosira cf. leptopus discriminate the western shelf, functioning as indicators of a less productive environment than the Rias Baixas. Thalassionema nitzschioides (Fig. 3b) has been considered as an indicator of less frequent upwelling conditions in the near Portuguese coast (Abrantes, 1988). In the western Galician shelf maximum values for this species are located in middle shelf positions, far from the coastline, in an area where upwelling influence decreases (Prego and Bao, 1997). Its preferential distribution in the western shelf is in accordance with the more episodic upwelling conditions in this area (Tenore et al., 1995). Moreover, it has been suggested that small Thalassiosira species become more important in the sediments in areas where the nutrient supply is more consistent (Abrantes, 1988). Although upwelling can be more episodic in the western shelf, production in this sector can be very important even during non-upwelling conditions due to nutrient outwelling from the Rias Baixas (Varela, 1992). We suggest that the relative increase of Thalassionema nitzschioides and Thalassiosira cf. leptopus in the western shelf is related to the coexistence of weaker upwelling conditions with a more consistent nutrient supply due to quasi-permanent outwelling from the Rias Baixas.

A mixture of benthic freshwater and marine pelagic diatoms characterize the outer shelf palimpsest deposits of the western shelf (Bao et al., 1995). Fragilaria pinnata and Nitzschia marina, both included in the discriminant analysis, are representative of these palimpsest deposits. Both have a minor to moderate contribution to the derived discriminant functions in comparison with the upwelling related Thalassionema 
nitzschioides and Thalassisora cf. leptopus (Table 2; Fig. 4). As a consequence, in spite of the existence of reworked assemblages in the western shelf, mesoscale differences in upwelling influence along the coast can be considered as the primary signals preserved in the diatom assemblages in this area.

The northern Galician shelf appears to be characterized by Paralia sulcata (Fig. 3c). Due to its resistance to dissolution, high abundances of this species in coastal sediments have been regarded as representing otherwise severely dissolved diatom assemblages (Schrader et al., 1993). In spite of this, the abundance of Paralia sulcata in the sediments of the Galician northern shelf may reflect not only its preferential preservation in strong dissolution conditions but also the distinct effects of upwelling along the coast. Paralia sulcata has been reported in upwelling affected areas as an indicator of regional upwelling which occurs in low numbers in the non-upwelling sectors (Abrantes and Sancetta, 1985). As it was said above, the increase of the resistant Paralia sulcata in the northern shelf is not accompanied by the increase in the also resistant Chaetoceros spores, suggesting that other processes besides dissolution also control the composition of the diatom assemblages (Abrantes, 1991a,b). Upwelling patchiness in the Galician northern shelf may be reflected in the underlying sediments by a Paralia dominated biofacies. This patchiness might bring an overall reflection in the sediments of typical winter mixing conditions associated with low phytoplankton abundances off the Galician coast when Paralia sulcata increases its abundance in the water column (Casas, 1995) rather than the influence of the upwelling season. This result is similar to the known maximum relative values of this species in surface sediments of the Gulf of California which closely follow low phytoplanktonic biomass levels (Round, 1967).

A combination of both dissolution and an impoverishment in productivity conditions of the northern shelf may explain why Paralia sulcata is the main species responsible in the discrimination of samples from this sector. As supply rate of siliceous skeletons increase and valves are progressively dissolved in the sediments, pore waters become more saturated in silica acting as a buffer against continued dissolution (Broecker and Peng, 1982; Pokras, 1986). A lesser incidence of upwelling in the northern shelf may bring lower productivity (Bode et al., 1994) and hence increased frustule dissolution in the sediments. Both factors, a minor incidence of upwelling conditions and poor 
preservability, should be taken into account in the interpretation of a Paralia dominated biofaties in downcore studies of the upwelling influenced continental shelves.

\section{Conclusions}

Differences in absolute valve abundances and composition of the diatom assemblages in surface sediments of the Galician continental shelf allow to distinguish different specific taxa dominated biofacies according to well defined oceanographic features of the overlying water column. Although evidences exist of reworked and transported assemblages, differences in upwelling influence along the coast are the primary signals preserved at a mesoscale in the diatom assemblages.

A high productivity biofacies which is represented by inside the Rias Baixas is characterized by a Chaetoceros resting spores dominated assemblage and high absolute diatom abundances (maximum values of (70-87.5) x $10^{6}$ valves $\mathrm{g}^{-1}$ ) comparable to those of the upwelling region off Peru. This facies is therefore a powerful indicator of high productivity associated with intense upwelling conditions.

The presence in the western shelf of palimpsest deposits related to past low-stands of sea-level and of Chaetoceros spores exported by the Rias Baixas do not mask differences in the upwelling signal on the seafloor of this sector. A powerful multivariate discriminant function shows that Thalassionema nitzschioides and Thalassiosira are the main responsibles discriminating a biofacies which indicate the effects of weaker upwelling conditions and primary productivity mainly controlled by constant nutrient inputs by coastal outwelling phenomena rather than by upwelling.

Strong upwelling patchiness and lower productivity is characteristic of the northern shelf, giving a diatom assemblage which is discriminated by the increased presence of Paralia sulcata and low absolute diatom abundances. Superimposed on this scheme, the effect of dissolution on the sediments, probably as a consequence of a minor opal flux due to decreasing primary productivity in this sector, cannot completely be disregarded. The combined effects of both factors make difficult the identification of an unequivocal upwelling related cause for the Paralia dominated biofacies in downcore studies. 
The obtained results show the extent and limitations to which diatom biofacies can be used for the reconstruction of past upwelling conditions at a regional scale in continental shelf sediments. The cosmopolitan character of the indicator taxa found may contribute to the understanding of the significance of the fossil diatom record in different upwelling affected continental shelves of the world. Strong upwelling conditions and high productivity mainly due to coastal outwelling give clear distinct diatom biofacies. Lower productivity conditions related to the weak and more discontinuous effects of upwelling are associated with diatom assemblages enriched in resistant forms which may also be concentrated by the effect of dissolution. This makes of limited value the use of these assemblages in downcore studies as tracers of upwelling.

\section{Acknowledgements}

We gratefully acknowledge the generous contribution of samples from Jorge Rey Salgado of the Instituto Español de Oceanografia (Fuengirola, Malaga). Special thanks are due to Lloyd Burckle, Fatima Abrantes and Connie Sancetta who commented on an earlier draft of this paper and to Hans Schrader and Björg Stabell for their critical review of the manuscript. We also thank Juan Ramon Vidal Romani for his encouragement and stimulating discussions. This work was supported by the European Union in the framework of the MAST programme, contract no. MAS2-CT93-0069 (Ocean Margin Exchange, OMEX). It is also a contribution to projects XUGA10307B93 (Xunta de Galicia) and APC-950010 (Direccion General de Investigacion Cientica y Tecnica).

\section{References}

Abrantes, F., 1988. Diatom assemblages as upwelling indicators in surface sediments of Portugal. Mar. Geol. 85, 15-39.

Abrantes. F., 1991a. Increased upwelling off Portugal during the last glaciation: diatom evidence. Mar. Micropaleontol. 17, 285-310.

Abrantes, F., 1991b. Variability of upwelling off NW Africa during the latest

Quaternary: diatom evidence. Paleoceanography 6, 431-460. 
Abrantes, F., Sancetta, C., 1985. Diatom assemblages in surface sediments reflect coastal upwelling off southern Portugal. Oceanol. Acta 8, 7-12.

Bao, R., Vidal, J.R., Varela, M., 1995. Diatomeas dulceacuicolas y episodios regresivos en el margen continental de Galicia. In: Actas $3^{\mathrm{a}}$ Reuniao do Quaternario Iberico. Universidade de Coimbra. Coimbra, pp. 237-240.

Blanton, J.O., Atkinson, L.P., Fernandez de Castillejo, F., Lavin, A., 1984. Coastal upwelling off the Rias Bajas, Galicia, northwest Spain I: hydrographic studies. Rapp. P.-v. Réun. Cons. int. Explor. Mer 183, 79-90.

Bode, A., Casas, B., Varela, M., 1994. Size-fractionated primary productivity and biomass in the Galician shelf (NW Spain): net plankton versus nanoplankton dominance. Sci. Mar. 58, 131-141.

Broecker, W.S., Peng, T.H., 1982. Tracers in the Sea. Eldigio Press, Palisades, NY, 690 pp.

Casas, B., 1995. Composicion, biomasa y produccion del fitoplancton en la costa de La Coruña: 1989-1992. Ph. D. Dissert., Univ. Santiago de Compostela, Spain, 340 pp.

Estrada, M., 1984. Phytoplankton distribution and composition off the coast of Galicia (northwest of Spain). J. Plankton Res. 6, 417-434.

Figueiras, F.G., Castro, C.G., Arbones, B., Villarino, M.L., 1997. Mapping primary production of Galician coast (NW Spain) during an upwelling event. In: Third EU Conference on Exchange Processes at the Continent/Ocean Margins in the North Atlantic, Vigo, Spain (Abstract).

Fraga, F., 1981. Upwelling of the Galician coast, northwest Spain. In: Richards, F.A. (Ed), Coastal Upwelling. Am. Geophys. Union, Washington, DC, pp. 176-182.

Fraga, F., Mouriño, C., Manriquez, M., 1982. Las masas de agua en la costa de Galicia: junio-octubre. Inv. Pesq. Res. Exp. Cient. 10. 51-77.

Fütterer, D.K., 1983. The modern upwelling record of northwest Africa. In: Thiede, J., Suess, E. (Eds.), Coastal Upwelling. Its Sediment Record, 2. Plenum, New York, pp. $105-121$.

Gonzalez, J.J., Cabanas, J.M., Gonzalez-Quijano, A., 1982. Primary productivity in winter in the Ria of Pontevedra (NW of Spain) and the changes caused by the contamination. ICES Biol. Ocean. Commt. CM 2, 1-133.

Gonzalez, N., Cabanas, J.M., Iglesias, M.L., Nunes, M.T., 1984. Contribucion al estudio oceanografico de la plataforma continental frente a las rias gallegas. Bol. Inst. Esp. Oceanogr. 1, 1-10. 
Guillard, R.R.L., Kilham, P., 1977. The ecology of marine planktonic diatoms. In:

Werner, D. (Ed.), The Biology of Diatoms. Blackwell, Oxford, pp. 372-469.

Harvey, J., 1982. $\theta$-S relationship and water masses in the eastern north Atlantic. DeepSea Res. 29, 1021-1033.

Huntsman, S.A., Barber, R., 1977. Primary production of northwest Africa: the relationship to wind and nutrient conditions. Deep-Sea Res. 24, 25-33.

Kennett, J., 1982. Marine Geology. Prentice-Hall, Englewood Cliffs, NJ. 813 pp.

Lopez-Jamar, E., Cal, R.M., Gonzalez, G., Hanson, R.B., Rey, J., Santiago, G., Tenore, K.R., 1992. Upwelling and outwelling effects on the benthic regime of the continental shelf off Galicia. NW Spain. J. Mar. Res. 50, 465-488.

Margalef, R., 1959. Nuevos datos para el estudio de la historia de la Ria de Vigo desde la ultima glaciacion. Mem. R. AC. Cienc. Artes Barcelona 33, 23-35.

McClain, C.R., Chao, S., Atkinson, L.P., Blanton, J.O., Castillejo de, F., 1986. Wind driven upwelling in the vicinity of Cape Finisterre, Spain. J. Geophys. Res. 91, 8470-8486.

McManus, D.A., 1975. Modem versus relict sediments on the continental shelf. Geol. Sot. Am. Bull. 86, 1154-1160.

Nie, N.H., Hadlai Hull, C., Jenkins, J.G., Steinbrenner, K., Bent, D.H., 1975. Statistical Package for the Social Sciences. McGraw-Hill, New York, 675 pp.

Nunes, T., Marina, J., Iglesias, M.L., Gonzalez, N., Campos, M.J., Cabanas, J.M., 1984. Condiciones ambientales, producción primaria y sucesion de especies fitoplanctonicas en la Ria de Arousa (NW de España). Cuad. Area Cienc. Marinas, Sem. Estud. Galegos 1, 163-172.

Pokras, E.M., 1986. Preservation of fossil diatoms in Atlantic sediment cores: control by supply rate. Deep-Sea Res. 33, 893-902.

Prego, R., 1990. Las sales nutrientes en las rias gallegas. Inf. Tecn. Sci. Mar. 157, 31

Prego, R., 1993. General aspects of carbon biogeochemistry in the ria of Vigo. northwestern Spain. Geochim. Cosmochim. Acta 57, 2041-2052.

Prego, R., Bao, R., 1997. Upwelling influence on the Galician coast: silicate in shelf water and underlying surface sediments. Cont. Shelf Res, 17, 307-318.

Prego, R., Bao, R., Howland, R., 1995. The biogeochemical cycling of dissolved silicate in a Galician ria. Ophelia 42, 301-318.

Rey, J., Diaz del Rio, V., 1987. Structure of recent sedimentary units in the Galician continental shelf. Cuad. Lab. Xeol. Laxe II, 35-45. 
Rios, A.F., Perez, F.F., Fraga, F., 1991. Water masses in the upper and middle north Atlantic Ocean east of the Azores. Deep-Sea Res, 39, 645-658.

Round, F.E., 1967. The phytoplankton of the Gulf of California, Part I. Its composition, distribution and contribution to the sediments. J. Exp. Mar. Biol. Ecol. 1, 76-97.

Schrader, H.J., Gersonde, R., 1978. Diatoms and silico flagellates. Utrecht Micropaleontol. Bull. 17. 129176.

Schrader, H., Sorknes, R., 1991. Peruvian coastal upwelling: late Quaternary productivity changes revealed by diatoms. Mar. Geol. 97, 233-249.

Schrader, H., Swanberg, I.L., Lycke, A.K., Paetzel, M., Schrader, T., Schrader, T., 1993. Diatom-inferred productivity changes in the eastern eqautorial Pacific: the Quaternary record of ODP Leg 111, Site 677. Hydrobiologia 269-270, 137-151.

Schuette, G., Schrader, H., 1981a. Diatom taphocoenoses in the coastal upwelling area off south west Africa. Mar. Micropaleontol. 6, 131-155.

Schuette, G., Schrader, H., 1981b. Diatoms in surface sediments: a reflection of coastal upwelling. In: Richards, F.A. (Ed.). Coastal Upwelling. Am. Geophys. Union. Washington. DC. pp. 372-380.

Tenore, K.R., Gonzalez, N., 1975. Food chain patterns in the Ria de Arosa. Spain: an area of intense mussel aquaculture. 10th Eur. Symp. Mar. Biol.. Ostend. Belgium. 2, pp. 601-619.

Tenore, K.R., Alonso-Nova, M., Alvarez-Ossorio, M., Atkinson, L.P., Cabanas, J.M., Cal, R.M., Campos, H.J., Castillejo, F., Chesney, E.J., Gonzalez, N., Hanson, R.B., McClain, C.R., Miranda, A., Roman, M.R., Sanchez, J., Santiago, G., Valdes, L., Varela, M., Yoder, J., 1995. Fisheries and oceanography of Galicia. NW Spain: mesoscale spatial and temporal changes in physical processes and resultant patterns of biological productivity. J. Geophys. Res. 100, 10943-10966.

Varela, M., 1992. Upwelling and phytoplankton ecology in Galician (NW Spain) rias and shelf waters. Bol. Inst. Esp. Oceanogr. 8, 57-73.

Varela, M., Fuentes, J.M., Penas, E., Cabanas, J.M., 1984. Produccion primaria de las Rias Baixas de Galicia. Cuad. Area Cienc. Marinas. Sem. Estud. Galegos 1, 173182.

Williams, B.K., 1983. Some observations on the use of discriminant analysis in ecology. Ecology 64, 1283-1291.

Wooster, W.S., Bakun, A., McClain, D.R., 1976. The seasonal upwelling cycle along the eastern boundary of the north Atlantic. J. Mar. Res. 34, 131-141. 

Fig. 1. Galician continental shelf and geographical distribution of the sleeted 78 surface sediment samples collected during the Breogan cruises.

Fig. 2. Distribution pattern of (a) Lumber of diatom valves per gram of dry sediment and (b) preservation index

Fig. 3. Relative abundance of (a) Chaeteceros spp. resting spores, (b) Thalassionema nitzschioides and (c) Paralia suicata

Fig. 4. Plot of (a) the samples and (b) the species on the two functions derived from the discriminant analysis. $(\mathrm{R}=$ Rias Baixas; $\mathrm{W}=$ western shelf; $\mathrm{N}=$ northern shelf; Act. sen. $=$ Actinoptychus senarius; Chaet. spp. $=$ Chaetoceros spp. resting spores; Diat. spp. = Diatomaceae spp.; Dipl. did. = Diploneis didyma; Dipl. spp = Diploneis spp.; Frag. pinn. $=$ Fragilaria pinnata; Gram. ser. $=$ Grammatophora serpentina; Nav. spp. $=$ Navicula spp.; Nitz. mar. $=$ Nitzschia marina; Par. sul. $=$ Paralia sulcata; Pod. ste. $=$ Podosira stelliger; Tha. nitz. $=$ Thalassionema nitzschioides; Tha. fra. $=$ Thalassionema frauenfeldii; Thal. $\mathrm{cf}$. ecc. $=$ Thalassiosira $\mathrm{cf}$. eccentrica; Thal. $\mathrm{cf}$. lep. $=$ Thalassiosira cf. leptopus; Thal. cf. rot. = Thalassiosira cf. rotula; Trach. asp. $=$ Trachyneis aspera).

Table 1

Positions and water depths of surface sediment samples used in this study

\begin{tabular}{llllllll}
\hline Sample & Lat. (N) & $\begin{array}{l}\text { Long. } \\
(\mathrm{W})\end{array}$ & $\begin{array}{l}\text { Depth } \\
(\mathrm{m})\end{array}$ & $\begin{array}{l}\text { Sample } \\
\text { Lat. (N) }\end{array}$ & $\begin{array}{l}\text { Long. } \\
(\mathrm{W})\end{array}$ & $\begin{array}{l}\text { Depth } \\
(\mathrm{m})\end{array}$ \\
\hline 13 & $42^{\circ}$ & $8^{\mathrm{o}} 30.90^{\prime}$ & 18 & 82 & $43^{\circ}$ & $9^{\circ} 16.50^{\prime}$ & 164 \\
& $16.17^{\prime}$ & & & & $18.90^{\prime}$ & & \\
21 & $41^{\circ}$ & $8^{\circ} 45.33^{\prime}$ & 28 & 83 & $\begin{array}{l}43^{\circ} \\
21.00^{\prime}\end{array}$ & $9^{\circ} 21.00^{\prime}$ & 209 \\
& $14.77^{\prime}$ & & & & & \\
26 & $42^{\circ}$ & $8^{\circ} 49.90^{\prime}$ & 36 & 85 & $43^{\circ}$ & $9^{\circ} 06.00^{\prime}$ & 170 \\
& $12.20^{\prime}$ & & & & $25.50^{\prime}$ & & \\
31 & $42^{\circ}$ & $8^{\circ} 41.75^{\prime}$ & 37 & 86 & $43^{\circ}$ & $9^{\circ} 04.00^{\prime}$ & 154 \\
& $14.00^{\prime}$ & & & & $22.50^{\prime}$ & & \\
34 & $43^{\circ}$ & $8^{\circ} 25.50^{\prime}$ & 89 & 87 & $43^{\circ}$ & $8^{\circ} 52.50^{\prime}$ & 150 \\
& $31.00^{\prime}$ & & & & $27.50^{\prime}$ & & \\
\hline
\end{tabular}




\begin{tabular}{|c|c|c|c|c|c|c|c|}
\hline 35 & $\begin{array}{l}43^{\circ} \\
33.50^{\prime}\end{array}$ & $8^{\circ} 23.90^{\prime}$ & 100 & 88 & $\begin{array}{l}43^{\circ} \\
30.70^{\prime}\end{array}$ & $8^{\circ} 54.20^{\prime}$ & 167 \\
\hline 36 & $\begin{array}{l}43^{\circ} \\
28.00^{\prime}\end{array}$ & $9^{\circ} 00.30^{\prime}$ & 162 & 89 & $\begin{array}{l}43^{\circ} \\
34.00^{\prime}\end{array}$ & $8^{\circ} 57.00^{\prime}$ & 231 \\
\hline 37 & $\begin{array}{l}43^{\circ} \\
25.00^{\prime}\end{array}$ & $8^{\circ} 56.70^{\prime}$ & 147 & 90 & $\begin{array}{l}43^{\circ} \\
39.80^{\prime}\end{array}$ & $8^{\circ} 43.00^{\prime}$ & 214 \\
\hline 38 & $\begin{array}{l}43^{\circ} \\
20.80^{\prime}\end{array}$ & $8^{\circ} 47.60^{\prime}$ & 55 & 91 & $\begin{array}{l}43^{\circ} \\
33.80^{\prime}\end{array}$ & $8^{\circ} 42.00^{\prime}$ & 158 \\
\hline 39 & $\begin{array}{l}43^{\circ} \\
20.18^{\prime}\end{array}$ & $8^{\circ} 37.00^{\prime}$ & 55 & 92 & $\begin{array}{l}43^{\circ} \\
33.80^{\prime}\end{array}$ & $8^{\circ} 42.00^{\prime}$ & 158 \\
\hline 40 & $\begin{array}{l}43^{\circ} \\
25.25^{\prime}\end{array}$ & $8^{\circ} 44.10^{\prime}$ & 123 & 93 & $\begin{array}{l}43^{\circ} \\
30.60^{\prime}\end{array}$ & $8^{\circ} 47.00^{\prime}$ & 151 \\
\hline 41 & $\begin{array}{l}43^{\circ} \\
33.30^{\prime}\end{array}$ & $8^{\circ} 33.50^{\prime}$ & 142 & 95 & $\begin{array}{l}42^{\circ} \\
51.00^{\prime}\end{array}$ & $9^{\circ} 19.00^{\prime}$ & 110 \\
\hline 42 & $\begin{array}{l}43^{\circ} \\
27.80^{\prime}\end{array}$ & $8^{\circ} 31.30^{\prime}$ & 112 & 100 & $\begin{array}{l}42^{\circ} \\
16.00^{\prime}\end{array}$ & $9^{\circ} 11.00^{\prime}$ & 152 \\
\hline 43 & $\begin{array}{l}42^{\circ} \\
45.40^{\prime}\end{array}$ & $9^{\circ} 00.30^{\prime}$ & 30 & 102 & $\begin{array}{l}42^{\circ} \\
16.00^{\prime}\end{array}$ & $9^{\circ} 05.50^{\prime}$ & 120 \\
\hline 45 & $\begin{array}{l}41^{\circ} \\
53.00^{\prime}\end{array}$ & $8^{\circ} 58.50^{\prime}$ & 65 & 103 & $\begin{array}{l}42^{\circ} \\
41.50^{\prime}\end{array}$ & $9^{\circ} 12.00^{\prime}$ & 100 \\
\hline 48 & $\begin{array}{l}42^{\circ} \\
38.00^{\prime}\end{array}$ & $9^{\circ} 10.00^{\prime}$ & 116 & 105 & $\begin{array}{l}42^{\circ} \\
11.00^{\prime}\end{array}$ & $9^{\circ} 01.00^{\prime}$ & 116 \\
\hline 49 & $\begin{array}{l}42^{\circ} \\
14.50^{\prime}\end{array}$ & $9^{\circ} 01.00^{\prime}$ & 119 & 106 & $\begin{array}{l}42^{\circ} \\
11.00^{\prime}\end{array}$ & $9^{\circ} 07.00^{\prime}$ & 140 \\
\hline 50 & $42^{\circ} 15.5^{\prime}$ & $9^{\circ} 06.00^{\prime}$ & 138 & 107 & $\begin{array}{l}42^{\circ} \\
21.00^{\prime}\end{array}$ & $9^{\circ} 08.00^{\prime}$ & 132 \\
\hline 53 & $\begin{array}{l}42^{\circ} \\
25.50^{\prime}\end{array}$ & $9^{\circ} 10.50^{\prime}$ & 131 & 108 & $\begin{array}{l}42^{\circ} \\
11.00^{\prime}\end{array}$ & $9^{\circ} 14.00^{\prime}$ & 185 \\
\hline 54 & $\begin{array}{l}42^{\circ} \\
28.70^{\prime}\end{array}$ & $9^{\circ} 17.00^{\prime}$ & 146 & 109 & $\begin{array}{l}42^{\circ} \\
11.00^{\prime}\end{array}$ & $9^{\circ} 20.00^{\prime}$ & 230 \\
\hline 55 & $\begin{array}{l}42^{\circ} \\
35.00^{\prime}\end{array}$ & $9^{\circ} 15.00^{\prime}$ & 100 & 110 & $\begin{array}{l}42^{\circ} \\
06.00^{\prime}\end{array}$ & $9^{\circ} 18.00^{\prime}$ & 180 \\
\hline 57 & $\begin{array}{l}42^{\circ} \\
34.00^{\prime}\end{array}$ & $9^{\circ} 14.00^{\prime}$ & 227 & 111 & $\begin{array}{l}42^{\circ} \\
06.00^{\prime}\end{array}$ & $9^{\circ} 11.00^{\prime}$ & 148 \\
\hline
\end{tabular}




\begin{tabular}{|c|c|c|c|c|c|c|c|}
\hline 59 & $\begin{array}{l}43^{\circ} \\
37.00^{\prime}\end{array}$ & $9^{\circ} 20.50^{\prime}$ & 122 & 112 & $\begin{array}{l}42^{\circ} \\
06.00^{\prime}\end{array}$ & $8^{\circ} 57.50^{\prime}$ & 100 \\
\hline 60 & $\begin{array}{l}42^{\circ} \\
37.00^{\prime}\end{array}$ & $9^{\circ} 16.50^{\prime}$ & 109 & 113 & $\begin{array}{l}42^{\circ} \\
00.00^{\prime}\end{array}$ & $9^{\circ} 01.50^{\prime}$ & 116 \\
\hline 61 & $\begin{array}{l}42^{\circ} \\
40.50^{\prime}\end{array}$ & $9^{\circ} 19.00^{\prime}$ & 119 & 115 & $\begin{array}{l}42^{\circ} \\
00.00^{\prime}\end{array}$ & $9^{\circ} 08.00^{\prime}$ & 132 \\
\hline 62 & $\begin{array}{l}42^{\circ} \\
40.50^{\prime}\end{array}$ & $9^{\circ} 26.00^{\prime}$ & 145 & 116 & $\begin{array}{l}42^{\circ} \\
00.00^{\prime}\end{array}$ & $9^{\circ} 13.60^{\prime}$ & 145 \\
\hline 65 & $\begin{array}{l}42^{\circ} \\
43.20^{\prime}\end{array}$ & $9^{\circ} 13.20^{\prime}$ & 88 & 117 & $\begin{array}{l}42^{\circ} \\
06.00^{\prime}\end{array}$ & $9^{\circ} 04.00^{\prime}$ & 130 \\
\hline 66 & $\begin{array}{l}42^{\circ} \\
49.00^{\prime}\end{array}$ & $9^{\circ} 15.40^{\prime}$ & 94 & 120 & $\begin{array}{l}41^{\circ} \\
53.00^{\prime}\end{array}$ & $9^{\circ} 05.50^{\prime}$ & 114 \\
\hline 67 & $\begin{array}{l}42^{\circ} \\
46.20^{\prime}\end{array}$ & $9^{\circ} 22.20^{\prime}$ & 133 & 121 & $\begin{array}{l}42^{\circ} \\
24.50^{\prime}\end{array}$ & $9^{\circ} 01.70^{\prime}$ & 93 \\
\hline 68 & $\begin{array}{l}42^{\circ} \\
46.00^{\prime}\end{array}$ & $9^{\circ} 28.00^{\prime}$ & 143 & 124 & $\begin{array}{l}42^{\circ} \\
21.00^{\prime}\end{array}$ & $8^{\circ} 53.00^{\prime}$ & 47 \\
\hline 69 & $\begin{array}{l}42^{\circ} \\
50.00^{\prime}\end{array}$ & $9^{\circ} 23.00^{\prime}$ & 135 & 125 & $\begin{array}{l}42^{\circ} \\
31.80^{\prime}\end{array}$ & $8^{\circ} 53.00^{\prime}$ & 38 \\
\hline 70 & $\begin{array}{l}42^{\circ} \\
53.00^{\prime}\end{array}$ & $9^{\circ} 27.00^{\prime}$ & 157 & 128 & $\begin{array}{l}42^{\circ} \\
24.50^{\prime}\end{array}$ & $9^{\circ} 13.20^{\prime}$ & 150 \\
\hline 71 & $\begin{array}{l}42^{\circ} \\
57.00^{\prime}\end{array}$ & $9^{\circ} 21.83^{\prime}$ & 106 & 130 & $\begin{array}{l}42^{\circ} \\
17.80^{\prime}\end{array}$ & $8^{\circ} 56.80^{\prime}$ & 72 \\
\hline 74 & $\begin{array}{l}42 . \\
59.12^{\prime}\end{array}$ & $9^{\circ} 27.00^{\prime}$ & 162 & 131 & $\begin{array}{l}42^{\circ} \\
15.00^{\prime}\end{array}$ & $9^{\circ} 07.00^{\prime}$ & 142 \\
\hline 76 & $\begin{array}{l}43^{\circ} \\
06.50^{\prime}\end{array}$ & $9^{\circ} 19.00^{\prime}$ & 116 & 133 & $\begin{array}{l}41^{\circ} \\
58.00^{\prime}\end{array}$ & $9^{\circ} 20.30^{\prime}$ & 176 \\
\hline 77 & $\begin{array}{l}43^{\circ} \\
06.50^{\prime}\end{array}$ & $9^{\circ} 24.50^{\prime}$ & 153 & 143 & $\begin{array}{l}42^{\circ} \\
35.20^{\prime}\end{array}$ & $8^{\circ} 50.00^{\prime}$ & 18 \\
\hline 78 & $\begin{array}{l}43^{\circ} \\
06.30^{\prime}\end{array}$ & $9^{\circ} 32.30^{\prime}$ & 194 & 149 & $\begin{array}{l}42^{\circ} \\
36.10^{\prime}\end{array}$ & $8^{\circ} 53.70^{\prime}$ & 23 \\
\hline 80 & $\begin{array}{l}43^{\circ} \\
10.00^{\prime}\end{array}$ & $9^{\circ} 26.00^{\prime}$ & 157 & 164 & $\begin{array}{l}42^{\circ} \\
28.90^{\prime}\end{array}$ & $8^{\circ} 57.50^{\prime}$ & 60 \\
\hline 81 & $43^{\circ}$ & $9^{\circ} 20.00^{\prime}$ & 135 & 176 & $42^{\circ}$ & $8^{\circ} 56.30^{\prime}$ & 50 \\
\hline
\end{tabular}


Table 2

Results of discriminant analysis

\begin{tabular}{|c|c|c|c|c|c|c|c|}
\hline \multirow[t]{2}{*}{ Taxa } & \multicolumn{2}{|c|}{ ANOVA } & \multicolumn{2}{|c|}{$\begin{array}{l}\text { Discriminant } \\
\text { coefficient }\end{array}$} & \multicolumn{3}{|c|}{$\begin{array}{l}\text { Classification } \\
\text { coefficient }^{\mathrm{a}}\end{array}$} \\
\hline & $\mathrm{F}$ & $\mathrm{P}$ & Func. 1 & Func. 2 & 1 & 2 & 3 \\
\hline Actinoptychus senarius & 14.15 & 0.000 & 0.515 & 0.196 & -0.646 & -0.273 & 0.916 \\
\hline Chaetoceros spp. & 8.71 & 0.000 & -1.309 & 0.902 & 0.109 & -0.017 & -0.051 \\
\hline Diatomaceae spp. & 10.84 & 0.000 & 0.184 & -0.286 & -0.532 & 0.316 & 0.291 \\
\hline Diploneis didyma & 7.29 & 0.001 & -0.622 & -0.157 & 0.861 & 0.251 & -0.980 \\
\hline Diploneis spp. & 13.32 & 0.000 & -0.114 & 0.129 & 0.257 & -0.086 & -0.115 \\
\hline Fragilaria pinnata & 6.04 & 0.004 & 0.582 & 0.049 & -1.191 & -0.175 & 1.370 \\
\hline $\begin{array}{l}\text { Grammatophora } \\
\text { serpentina }\end{array}$ & 10.57 & 0.000 & 0.027 & 0.301 & 0.257 & -0.312 & 0.137 \\
\hline Navicula spp. & 6.88 & 0.002 & -0.596 & -0.002 & 0.932 & 0.099 & -0.875 \\
\hline Nitzschia marina & 12.55 & 0.000 & -0.264 & -0.555 & -0.023 & 0.434 & -0.398 \\
\hline Paralia sulcata & 20.55 & 0.000 & 1.413 & -0.389 & -0.155 & 0.021 & 0.167 \\
\hline Podosira stelliger & 15.73 & 0.000 & -0.003 & 0.078 & 0.060 & -0.025 & 0.019 \\
\hline $\begin{array}{l}\text { Thalassionema } \\
\text { frauenfeldii }\end{array}$ & 7.65 & 0.001 & 0.355 & 0.066 & -0.634 & -0.145 & 0.844 \\
\hline $\begin{array}{l}\text { Thalassionema } \\
\text { nitzschioides }\end{array}$ & 14.59 & 0.000 & -0.130 & -1.292 & -0.060 & 0.134 & -0.038 \\
\hline $\begin{array}{l}\text { Thalassiosira cf. } \\
\text { eccentrica }\end{array}$ & 5.03 & 0.009 & -0.050 & 0.346 & 0.189 & -0.125 & 0.018 \\
\hline $\begin{array}{l}\text { Thalassiosira cf. } \\
\text { leptopus }\end{array}$ & 12.35 & 0.000 & 0.136 & -0.886 & -0.666 & 0.647 & 0.024 \\
\hline Thalassiosira cf. rotula & 12.81 & 0.000 & 0.093 & 0.585 & 0.161 & -0.192 & 0.119 \\
\hline Trachyneis aspera & 9.06 & 0.000 & 0.541 & 0.082 & -0.891 & -0.171 & 1.211 \\
\hline Constants & - & - & - & - & -3.352 & -2.323 & -3.626 \\
\hline
\end{tabular}

${ }^{a} 1$. Analysis of variance for sectors to test the significance of equality of group means for each species. 2. Standardized discriminant coefficients which measure the 
discriminating power of each taxon for each function. 3. Fisher's classification coefficients for each taxon.

Table 3

Classification of samples by the discriminant functions derived from diatom data

\begin{tabular}{llllll}
\hline Group & Rias B. & W shelf & N shelf & Total & Percent correct \\
\hline Rias Baixas & 9 & 2 & 0 & 11 & 81.8 \\
W shell & 4 & 31 & 2 & 37 & 83.8 \\
N shell & 0 & 3 & 21 & 24 & 87.5 \\
Total & 13 & 36 & 23 & 72 & 84.7 \\
\hline
\end{tabular}

